\title{
Discovery of a Late Miocene mammalian fauna from Siziwang Banner, Inner Mongolia, and its paleozoogeographical significance
}

\author{
DENG Tao ${ }^{1 *}$, LIANG Zhong ${ }^{1,2}$, WANG ShiQi $^{1}$, HOU SuKuan $^{1,3}$ \& LI Qiang ${ }^{1}$ \\ ${ }^{1}$ Key Laboratory of Evolutionary Systematics of Vertebrates, Institute of Vertebrate Paleontology and Paleoanthropology, Chinese Academy of \\ Sciences, Beijing 100044, China; \\ ${ }^{2}$ China Geological Library, Beijing 100083, China; \\ ${ }^{3}$ Graduate University of the Chinese Academy of Sciences, Beijing 100049, China
}

Received May 10, 2010; accepted October 27, 2010

\begin{abstract}
The Wulanhua Fauna ( 7 Ma) derives from the basal part of Late Miocene red clays in Siziwang Banner, Inner Mongolia. Chinese red clay deposits are rich in fossils of the Hipparion fauna, and are relatively widely distributed across Shanxi, Shaanxi, Henan, and Gansu provinces. The Mongolian Plateau also contains well-developed Neogene deposits, especially in central Inner Mongolia, where a sequence of mammalian faunas has been identified. The discovery of the Wulanhua Fauna provides an important indicator of the paleogeographical distribution of the Hipparion fauna, and this study also contributes to a better understanding of the climatic and environmental significance of red clays. Most forms of the Wulanhua Fauna are the same as or close to taxa within the Baode Fauna. However, some forms are slightly more derived than those of the Baode Fauna, which may indicate a slightly younger geological age of about $7 \mathrm{Ma}$. The components of the Wulanhua Fauna suggest that the habitat was a typical steppe and therefore yield direct evidence to delineate the boundary between the east and west subregions of the Late Miocene Hipparion fauna in North China.
\end{abstract}

Siziwang Banner, Inner Mongolia, Late Miocene, red clay, mammal, zoogeography

Citation: Deng T, Liang Z, Wang S Q, et al. Discovery of a Late Miocene mammalian fauna from Siziwang Banner, Inner Mongolia, and its paleozoogeographical significance. Chinese Sci Bull, 2011, 56: 526-534, doi: 10.1007/s11434-010-4259-0

The central Inner Mongolia area, including Xilin Gol League and part of the region around Ulan Qab City is rich in Neogene mammalian fossils, especially shovel-tusked elephants of the classical Tunggur tableland and micromammals of the Ertemte locality, which have been well-known for many years $[1,2]$. On the other hand, until now only a few mammals have been found in the Late Miocene red clays of this region, which are similar to the Hipparion Red Clay fauna in North China. Recently, a significant number of mammalian fossils were discovered at a red clay exposure south of Wulanhua Town, Siziwang Banner (Figure 1). The excavated fossils and their taphonomy indicate that they belonged to the Late Miocene Hipparion fauna. Chilotherium anderssoni was the most abun-

*Corresponding author (email: dengtao@ivpp.ac.cn) dant species within the specimens recovered. Late Miocene Hipparion fossil localities are numerous in China, especially in the red clay deposits in northwestern China. Conversely, fossil localities of the Hipparion fauna are comparatively infrequent in eastern China, and generally are preserved in fluvial sandstones or lacustrine marlites. Thus, their sedimentary environments are distinctly different from those in northwestern China. The Chinese Miocene mammalian faunas differ in a west-east direction, which is consistent with geographical patterns of the area. In addition, similar evidence has been described for the Early Miocene in previous studies [3]. However, it still is unclear as to whether these differences existed during the Late Miocene, and where exactly was the paleozoogeographical boundary situated between the east and west regions. These questions have been the focus of interest for Chinese Neogene researchers. 


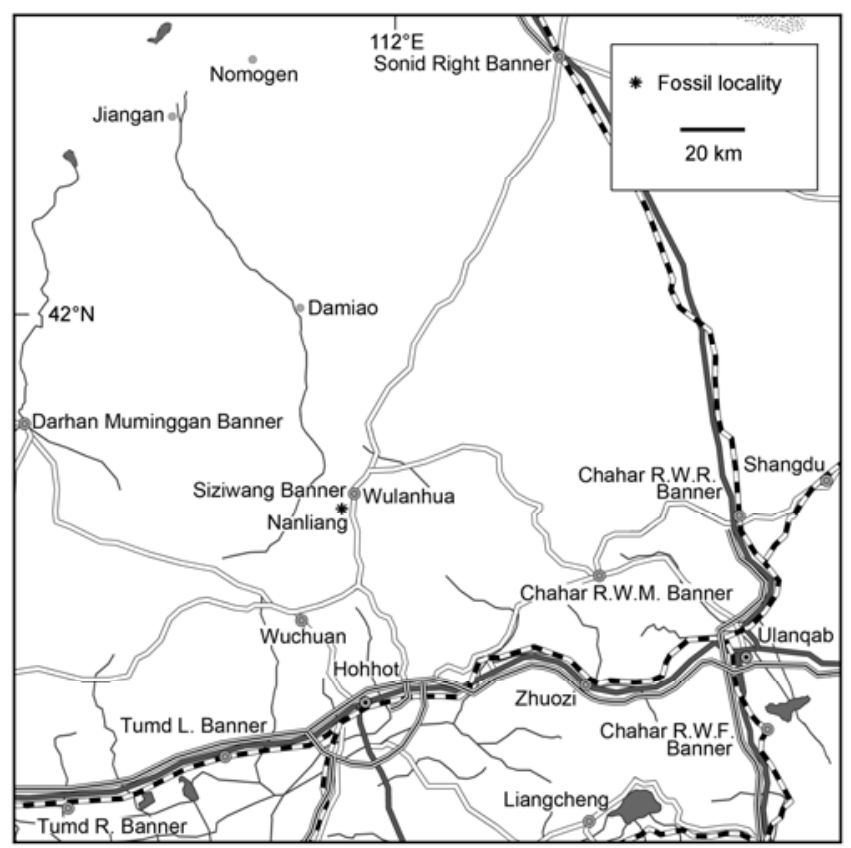

Figure 1 Geographical location of the Wulanhua fossil locality in Siziwang Banner.

The red clay deposits of Siziwang Banner are located relatively eastward in China, and the fossil locality of the Hipparion Red Clay at Wulanhua is to the north in China. The particular geographical position of this locality provides an opportunity to answer some of the questions mentioned above. In recent years, we have investigated the Wulanhua fossil locality with regard to its in situ taphonomy, and we have identified the excavated and collected fossils. Our work demonstrates that these mammalian fossils derived mainly from the basal part of the red clay exposure at this locality. This section has a thickness of about $23 \mathrm{~m}$ (Figure 2) and includes a new rodent species in its lower part. Based on the fossil assemblage, the age of the Wulanhua Fauna is slightly later than that of the Baode Fauna.

Across North China, fossil localities with rich mammals from Late Miocene red clays are relatively numerous [4], especially in Baode (Shanxi), Fugu (Shaanxi), Xin'an (Henan), and Linxia (Gansu). Among them, the most famous and first discovered locality is Baode in Shanxi Province

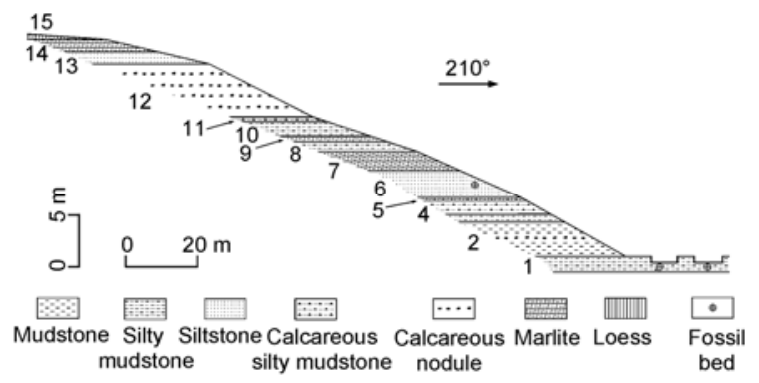

Figure 2 Stratigraphic section of the Wulanhua fossil locality in Siziwang Banner.
[5-8]. This locality was found in the 1920s, at which point the Austrian paleontologist O. Zdansky began to organize systematic and scientific excavations from 1922 onward. A large number of specimens were collected from Baode, including many well-preserved skulls and teeth that represent at least 57 species of large mammals [9], with a geological age of 7.2 Ma [10,11]. Most fossil members of the Hipparion fauna collected from Wulanhua are very similar to those of the Baode Fauna. The stratigraphy and paleontology of the Wulanhua locality are reported herein in order to add to the Neogene sequence of mammalian faunas in central Inner Mongolia, and to provide important evidence to determine the boundary between the Late Miocene mammalian east-west subregions in North China.

\section{Stratigraphy}

Nanliang is located at $3 \mathrm{~km}$ south to Wulanhua Town, Siziwang Banner, Ulan Qab City, Inner Mongolia Autonomous Region (Figure 1). The fossil locality is situated $250 \mathrm{~m}$ west of the Hohhot-Xilinhot highway (Provincial highway 101). Fossils are concentrated in the quarry of the Nanliang brick factory and in the middle part of the south slope of a small hill. Clay digging formed a 3 meter-high escarpment of red clays, in front of which fossils are concentrated on a flat area $\left(41^{\circ} 29^{\prime} 45.4^{\prime \prime} \mathrm{N}, 111^{\circ} 41^{\prime} 31.1^{\prime \prime} \mathrm{E}\right.$, elevation of $\left.1490 \mathrm{~m}\right)$. Two pits have been excavated scientifically, with a large number of mammalian fossils preserved in situ. In addition, some fossils have been found in the red clay escarpment. A new anchithere species, Sinohippus robustus, was reported from this locality [12]. The slope behind the escarpment is covered by grass, on which an artificial section was dug to expose the Late Miocene red clay deposits. This section starts from the lowest point of the fossil pit, and ends at the top of the hill, with a total thickness of about $23 \mathrm{~m}$ (Figure 2 ). The entire section consists of red clays, intercalated with some marlite bands, and its base is not exposed. This section is described from top to bottom as follows:

Quaternary

15 Late Pleistocene loess and modern soil $\sim 0.5 \mathrm{~m}$ Upper Miocene

$$
\text { 〜 Disconformity }
$$

14 Yellowish-brown marlites indurated by cement, with high density and abundant iron-manganese growths $(<1 \mathrm{~mm}$ diameter). Miarolitic pores and fissures are abundant $(<1$ $\mathrm{mm}$ diameter). $1.2 \mathrm{~m}$ thick.

13 Brownish-red muddy siltstones, poorly cemented. Calcareous deposits occur in some fissures. This layer contains white calcareous muddy granules (up to $7 \mathrm{~mm}$ diameter). Small black granules of metamorphic rocks are infrequent (4 mm diameter).

$1.15 \mathrm{~m}$ thick.

12 Purplish-red calcareous nodules, irregular in shape. They are angular blocks (15-20 cm average diameter) with calcareous cement. Fissures and pores are abundant, in which there are white calcareous coatings. Small miarolitic cavities $(1 \mathrm{~mm}$ diameter) are numerous. Glaebule structures occur inside the 
calcareous blocks. Occasional plant roots also found. $5.08 \mathrm{~m}$ thick.

11 Purplish-red calcareous silty mudstones with dense cements. Concentrated occurrences of iron-manganese grains and white calcareous grains have diameters smaller than 1 $\mathrm{mm}$. Uncommon calcareous micolitic pores also occur, with diameters of about $0.5 \mathrm{~mm}$.

$0.44 \mathrm{~m}$ thick

10 A paleosol of poorly cemented, purplish-red silty mudstones shows pedogenic crumb-structures, containing a great number of white angular marlite granules to $10 \mathrm{~mm}$ diameter.

$1.4 \mathrm{~m}$ thick.

9 Yellowish-brown marlites indurated by dense cement. There are many small miarolitic pores $(<1 \mathrm{~mm}$ diameter), some of which connect with one another to form irregular tube networks.

$0.52 \mathrm{~m}$ thick.

8 Light brownish-red silty mudstones with dense calcareous cement. There are calcareous miarolitic pores $(<1 \mathrm{~mm}$ diameter), and occasional white calcareous grains $(3 \mathrm{~mm}$ diameter).

$0.95 \mathrm{~m}$ thick.

7 Yellowish-brown marlites, containing abundant silt-sized grains, with dense cementation, low density, and white miarolitic pores ( $1 \mathrm{~mm}$ diameter). $\quad 1.85 \mathrm{~m}$ thick.

6 Light purplish-red muddy siltstones, containing few greyish-black, small granules (to $4 \mathrm{~mm}$ diameter) of metamorphic rocks and limestones. This layer produced the micromammal fossils of Brachyscirtetes sp. nov. $2.6 \mathrm{~m}$ thick.

5 Yellowish-brown marlites are dense and indurated. Occasional quartz sands are found, with diameters of about 1 $\mathrm{mm}$.

$0.32 \mathrm{~m}$ thick.

4 Light purplish-red silty mudstones with calcareous cements, containing a great number of white calcareous miarolitic pores ( $1 \mathrm{~mm}$ diameter).

$1.28 \mathrm{~m}$ thick.

3 Paleosols of poorly cemented, purplish-red silty mudstones form pedogenic crumb-structures, and contain black iron-manganese grains.

$0.77 \mathrm{~m}$ thick.

2 Light purplish-red mudstones with dense, indurated calcareous cements, contain a minute amount of silt. There are scattered iron-manganese grains and occasional angular calcite crystals $(4 \mathrm{~mm}$ diameter). The middle part of this layer has a level of spherical calcareous nodules (to $7 \mathrm{~mm}$ diameter).

$3.28 \mathrm{~m}$ thick.

1 Purplish-red silty mudstones with crumb-structures that contains abundant black iron-manganese coatings and rare white calcareous sand gains ( $\sim .5 \mathrm{~mm}$ diameter). The basal part of this layer bears a great diversity and number of mammalian fossils, including Hyaenictitherium sp., Machairodus sp., Sinohippus robustus, Hipparion teilhardi, H. platyodus, Chilotherium anderssoni, Cervovitus novorossiae, Palaeotragus microdon, Samotherium sinense, Gazella gaudryi, Plesiaddax depereti,? Tragoreas palaeosinensis and others.

$1.52 \mathrm{~m}$ thick.

Dipoides major, Hipparion sp. and Chilotherium sp. were reported to find from the red clays in the Bulage area of Damiao township about $60 \mathrm{~km}$ north of Wulanhua [13]. The strata in Wulanhua and Bulage are similar in lithology to the Wulantuke Formation of the Linhe district, Inner Mongolia. The latter is a series of poorly cemented, brownish-red deposits. Its lithology is simple, dominated by the interbedded grayish-yellow, brownish-red mudstones and brownish-gray, grayish-white fine siltstones, with occa- sional thinly layered marlites or conglomerates. The known mammalian fossils from the Wulantuke Formation include Ochotona sp., Sinohippus zitteli, Hipparion sp., Chilotherium sp., Cervus sp., and Gazella sp. [14].

\section{Mammalian fossils}

The following is the identification list of the known mammalian fossils collected from the Wulanhua locality: Brachyscirtetes sp. nov., Hyaenictitherium sp., Machairodus sp., Sinohippus robustus, Hipparion teilhardi, H. platyodus, Chilotherium anderssoni, Cervavitus novorossiae, Palaeotragus microdon, Samotherium sinense, Gazella gaudryi, Plesiaddax depereti, and ?Tragoreas palaeosinensis.

Most of the above-mentioned mammals are the same as or close to the members of the Baode Fauna, such as Machairodus sp., Chilotherium anderssoni, Cervavitus novorossiae, Palaeotragus microdon, Samotherium sinense, Plesiaddax depereti, ?Tragoreas palaeosinensis, and probably Hyaenictherium sp. Some forms are slightly more derived than those of the Baode Fauna, such as Sinohippus robustus, Hipparion teilhardi, H. platyodus, and Gazella gaudryi. Thus, they may indicate a somewhat later geological age. A few mammals have not been found in the Baode fauna, such as the rodent Brachyscirtetes sp. nov. Some important members of the Baode Fauna were absent in the Wulanhua Fauna until now. Except for an upper canine of Machairodus sp. and some hyaenid coprolites, most carnivores in the Baode Fauna have not been found in the $\mathrm{Wu}-$ lanhua Fauna, such as Indarctos, Plesiogulo, Parataxidea, Adcrocuta, and Metailurus. Missing forms in the Wulanhua Fauna also include the proboscidean Tetralophodon, the perissodactyls Dicerorhinus and Sinotherium, and the artiodactyls Chleuastochoerus, Sinotragus, Palaeoryx, etc. [9]. Diagnostic characters of the representative members of the Wulanhua Fauna are as follows:

Hipparion teilhardi is large-sized, with a length of 159.3 $\mathrm{mm}$ for the upper tooth row and $164 \mathrm{~mm}$ for the lower one. The bottom of the nasal notch is above the middle of $\mathrm{P} 2$. The anterostyle of P2 has a lingual constriction groove, which separates it from other portions of this tooth; the protocone is narrowly rounded, with sharp ends; the pli protoconule and pli caballine are large and long; the hypoconal constriction is unclear; and the hypoconal groove is distinct. The double knots of the lower cheek teeth are hipparionid [15]. The metaconid is nearly rounded, and the metastylid is subtriangular; the ectoflexid is wide and deep, and the lingual flexid is U-shaped, with a plication on each molar; the protoconid and hypoconid have convex labial walls that become stronger posteriorly. There is a marked plication on the middle of the bottom of the postflexid. The hypostylid is well-developed, and is strongly curved lingually on $\mathrm{p} 4$. The entoconid is large and beak-shaped on the lower premolars, and it is especially well-developed on p2. 
The paraconid of $\mathrm{p} 2$ is triangular in shape, with three rugose walls. The protoconid is expanded and bean-shaped. The hypoconid is narrow and long, and the metaconid is small and rounded. The double-knots of p3 have narrow necks, and the preflexid has a slender plication on its anterior and posterior parts, respectively (Figure 3(c)).

Hipparion platyodus has high facial crests, the anterior ends of which are above the P4/M1 boundary. The choana is widely U-shaped, and its bottom is at the level of the front of the protocone of M2. The infoldings of the incisors have weak wrinkles, and the vertical grooves on the labial and lingual walls are indistinct. The plications of the upper cheek teeth are strong, and the hypoconal groove is widely and deeply V-shaped. The hypocone strongly extends posterolingually, and the hypoconal constriction is absent. The protocone is short, with sharp ends, a rounded labial side, and a flat lingual side, especially on molars where it forms a semicycle. The anterostyle of P2 is short and rounded, the protocone is rounded, and the enamel plications of the pre- and post-fossettes are abundant and slender. The pli hypostyle is single, and located on the middle of the posterior wall, extending anteriorly, and the pli caballine is fine (Figure 3(e)). The length of the upper cheek tooth row is $157 \mathrm{~mm}$.

Chilotherium anderssoni: The skull roof is shallowly concave, and the parietal crests are widely separated. The facial crest turns upward at a near right angle. The postorbital process is distinct on the zygomatic bone, and the zygomatic arch is wide. The choana is narrowly V-shaped, and the sagittal crest on the basioccipital bone is thin and sharp. The length between the foramen magnum and the choana bottom is $236.5 \mathrm{~mm}$. The labial surface of the mandibular symphysis is widely concave, with a width of $155 \mathrm{~mm}$ at the anterior margin and $112 \mathrm{~mm}$ at the posterior constriction. The horizontal ramus is thick and moderately high. The ascending ramus is nearly vertical, with a width of $128 \mathrm{~mm}$, but its anterior margin is slightly inclined posteriorly. The upper part of its exterior wall is widely and deeply depressed,
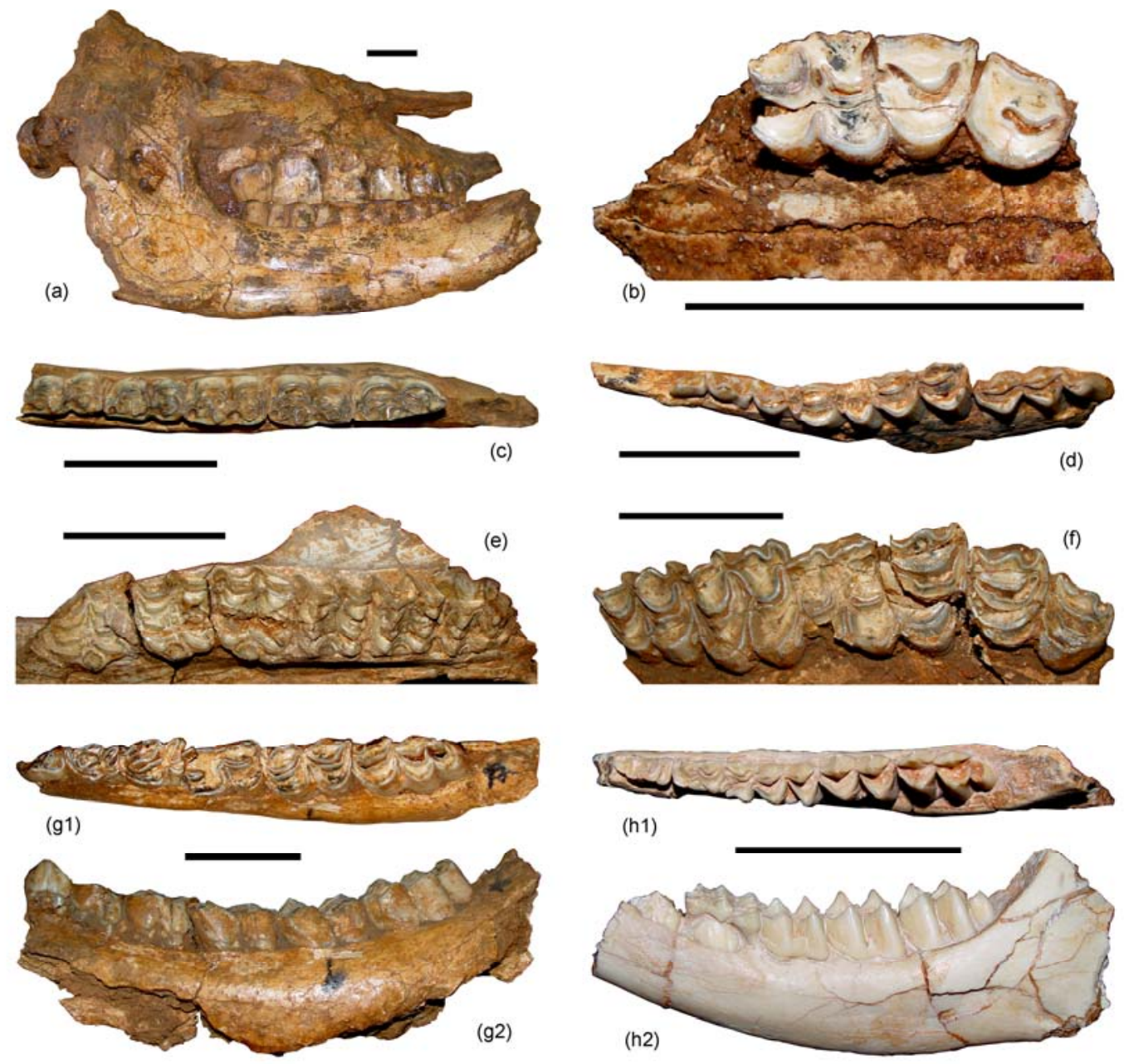

Figure 3 Some mammalian fossils of the Wulanhua Fauna. (a) Skull and mandible of Chilotherium anderssoni; (b) right upper cheek teeth (P3-M1) of ?Tragoreas palaeosinensis; (c) right lower cheek tooth row of Hipparion teilhardi; (d) left lower cheek tooth row of Palaeotragus microdon; (e) left upper cheek tooth row of Hipparion platyodus; (f), (g) samotherium sinense, (f) right upper cheek tooth row, (g) left lower cheek tooth row; (h) left lower cheek tooth row of Cervavitus novorossiae. (a), (g2), (h2) lateral view; others: occlusal view. Scale bar=5 cm. 
and the mandibular angle has a strongly prominent edge (Figure 3(a)). The ascending ramus is $193 \mathrm{~mm}$ high at the condyle. The upper cheek tooth rows are convergent anteriorly. The cheek teeth have rounded labial walls, covered by cement. The paracone rib is absent, and the parastyle fold is weak, which are diagnostic characters of this species [5]. The crista is absent on the cheek teeth. The premolars have well-developed lingual cingula, but the molars have none. The DP1 is small and shaped like a rounded triangle, and it persists in old individuals. The lingual wall of P2 is widely and shallowly grooved in the middle. The protoloph is posteriorly oblique, the labial wall is straight, the median and posterior valleys are closed, and the postfossette is larger than the medifossette. The parastyle of P3 is large and strongly prominent anteriorly. The protocone is large, not constricted, and connects with the hypocone to close the median valley. The protocone and hypocone are not rounded, with angular anterior and posterior ends, respectively. The crochet is robust, with a rounded end, and the posterior valley is narrow and deep. The protoloph and metaloph of $\mathrm{P} 4$ are oblique, and the antecrochet is well-developed and posteriorly extended to join the hypocone so that the median valley is closed. The posterior valley is wide and deep. The labial wall of M1 is undulated, the parastyle is large and anteriorly prominent, with a flat end, and the protocone and hypocone are lingually flat, with the former constricted. The antecrochet and crochet are robust; the protoloph and metaloph are posteriorly oblique, and the latter is short. The posterior valley is wide and deep. M2 is similar to M1 in shape, but the protocone of M2 is not constricted on the upper part of the crown, the metastyle is more developed, and a weak mesostyle is seen on the upper surface of the labial wall. The occlusal outline of M3 is nearly triangular, the protoloph is posteriorly oblique, the posterior part of the ecto-metaloph is lingually curved, the parastyle is large and prominent, the protocone is constricted, with a flat lingual margin, the crochet is robust and long, the antecrochet is relatively long, and its end reaches the entrance of the median valley. The inner half of the anterior cingulum is well developed, the lingual cingulum is absent, and the posterior cingulum is widely plate-like. $C h$. anderssoni is the dominant species in this locality.

Samotherium sinense has moderately hypsodont teeth with roughly rugose enamel. Except for a left M2 with a well-developed median pillar, other known cheek teeth have none. The fossettes of the premolars are narrow and long, the labial walls connect to each other, the mesostyle is strong, and the metastyle is weak. The lingual cingulum of $\mathrm{P} 2$ is absent, but those of P3 and P4 are well-developed. The labial cingulum is absent on each upper premolar. The upper molars are square and robust, without cingula. M2 is the largest tooth, and M3 is slightly constricted at the back. The median rib of the labial wall is strong and anteriorly shifted. The anterior labial valley is narrow and deep, the posterior labial valley is wide and shallow, and the parastyle and mesostyle are well-developed. The paracone rib is rounded, the metacone rib is weak or absent, and the anterior and posterior wrinkles are strong and sharp. Both the paracone and metacone are fused. The parastyle and metastyle are oblique anteriorly and posteriorly, respectively (Figure 3(f)). The lower cheek teeth lack cingula, and the metaconid and entoconid are lingually convex. The length of the lower cheek tooth row is $194.5 \mathrm{~mm}$. The lower premolars are large, with strong anterior and weak posterior lobes. The anterior fossette on p3 and p4 is closed, narrow and long longitudinally, while the posterior fossette is nearly closed, narrow and long transversely, and the metaconid is well-developed. The anterior labial crescent is flat on $\mathrm{m} 1$ and $\mathrm{m} 2$, but rounded on other cheek teeth. The talonid of $\mathrm{m} 3$ is relatively developed, and its crescents are $3 / 4$ of a circle, the lingual side of which extends anteriorly to connect to the posterior extension of the entoconid (Figure 3(g)).

Palaeotragus microdon is moderately hypsodont, with slightly rugose enamel. The upper premolars are robust, the single lingual crescent has an inner process extending into the fossette, and the lingual cingulum is absent. M1 is trapezoid in occlusal outline, wider labially than lingually, the median pillar is absent, the parastyle and mesostyle are well-developed, and the metastyle is posteriorly oblique. The paracone and metacone contact each other, but are not fused. The paracone rib is rounded, and the metacone rib is low and narrow. The lower premolars are relatively small. The p3 lacks a lingual wall, with markedly rugose enamel. The labial crescents of lower molars are relatively flat, the median pillar is absent between the protoconid and hypoconid, the lingual sides of the metaconid and entoconid are relatively flat, and the metastylid is weak. The talonid of $\mathrm{m} 3$ is narrow and long (Figure 3(d)).

Cervavitus novorossiae has brachydont cheek teeth without cingula, but with short and sharp basal pillars. The upper premolars have both lingual and labial crescents. The neocrista and medial crista are distinct, and the paracone rib is well-developed. The lingual median groove of P2 is weak, and the lingual walls of P3 and P4 are rounded. The mesostyles of the upper molars are well developed, and the accessory plications are present in the medifossettes. The lower premolars have the Palaeomeryx-folds, but the molars have none. The $\mathrm{p} 4$ is primitive, the paraconid and entoconid are lingually extended, the metaconid is narrow and long, the anterior and median valleys are almost closed, but the metaconid is not fused with the paraconid and entoconid. The entoconid extends lingually and covers the entrance of the talonid. The posterior valley is well-developed. The mesostylids of the lower molars are well-developed. The talonid of $\mathrm{m} 3$ is small, short, and rounded (Figure 3(h)).

Plesiaddax depereti is large-sized. The skull is robust, with a flat roof, and curved at the level in front of the horn base (Figure 4(a)). The nasals are narrow. The orbit is rounded and projected laterally, with an anterior rim at the level behind M3. The preorbital fossa is marked. The 

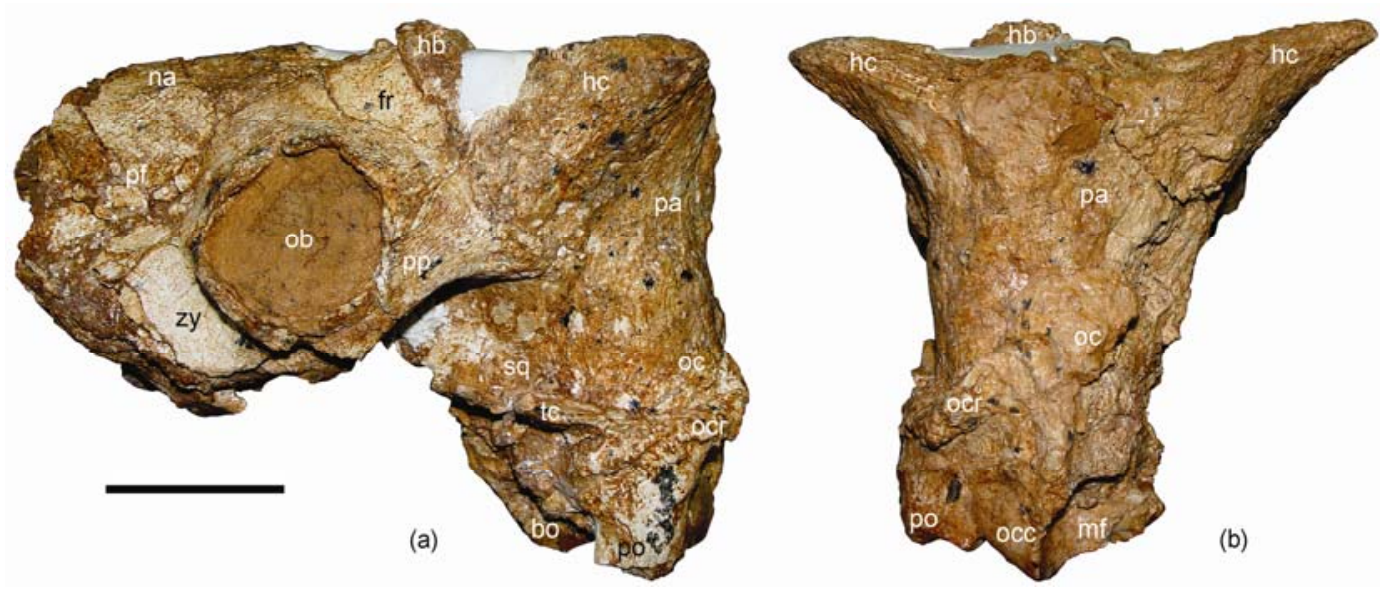

Figure 4 Skull of Plesiaddax depereti from Wulanhua. (a) Lateral view; (b) occipital view. Scale bar=5 cm. bo, basioccipital; fr, frontal; hb, horn base; hc, horn core; mf, magnum foramen; na, nasal; ob, orbit; oc, occipital; occ, occipital condyle; ocr, occipital crest; pa, parietal; pf, preorbital fossa; po, paroccipital process; pp, postorbital process; sq, squamosal; tc, temporal crest; zy, zygomatic.

cranium is short. The proportion of the skull behind horns is steep, at the same level with the occipital surface. The parietal crests are weak. The parietal bone is narrower than the occipital bone, and the lateral part of the occipital crest is robust and prominent (Figure 4(b)). A pair of horns is situated on the posterior part of the cranium, and their bases are expanded surround the bony cores with sharp tips. The horn cores are situated behind the orbits, and horizontally extended toward both sides of the skull. The horn base occupies a large area on the frontal surface, without a pedicle. The basioccipital bone is short and wide, hexagonal in shape. There are cristae in the fossettes of the upper cheek teeth. The upper molars are low-crowned, much longer than wide. The enamel wrinkles are distinct, the pillar is absent, and the labial ribs are weak. The lower molars lack pillars.

?Tragoreas palaeosinensis has a dolichocephalic skull, only slightly curved. The cheek teeth are brachydont, without basal pillars (Figure 3(b)). The premolar row is short, with weak cristae in the back of the fossettes. P3 is comparatively long, and P4 is short and wide. P2 and P3 are approximately semicircular, with a slightly concave labial surface, a well-developed metastylid, and a rounded lingual surface. P4 is a narrow semicircle, with a slightly convex labial surface, a rounded lingual surface, and marked paraand meta-styles, and the labial ribs disappear towards the crown base. The parastyle and mesostyle of the upper molars are well developed, the metastyle is weak, the anterior labial rib is apparent, and the central cavity is large. M1 is small, wider than long, while M2 and M3 are large, longer than wide. The metastyle of M3 is large and posteriorly prominent. The labial fold is absent in the anterior margins of the lower molars.

Gazella gaudryi: The skull is narrow and long. The cranial part behind the horn cores is short, belonging to the brachycephalic type. The occipital surface is narrow and high, with a faint median crest. The basioccipital region is trapezoid, with a narrow anterior margin. The horn cores are slender, widely separated, slightly divergent, gently oblique laterally, and curved posteriorly, with an oval cross section, marked vertical edges, and shallow grooves between edges. The total length of the horn core is $94.5 \mathrm{~mm}$, and the antero-posterior diameter of the base is $23 \mathrm{~mm}$. The molars are hypsodont, with weak ribs, but without pillars. The length of the lower cheek tooth row is $51 \mathrm{~mm}$.

Brachyscirtetes sp. nov. is a small species of this genus. The dental occlusal morphology is weakly lophodont. The paracone of M2 is relatively bunodont. The mesoloph and posteroloph of M2, and the mesolophid of $\mathrm{m} 2$ are not fused with the paracone, metacone and metaconid, respectively. The protoconid and metaconid of $\mathrm{ml}$ are approximately longitudinally symmetrical, orientated antero-labially and antero-lingually, respectively, with an obtuse angle between them. The anterior ectolophid is long and near the longitudinal axis.

As mentioned above, most forms of the Wulanhua Fauna are the same as or closely related to those of the Baode Fauna, but the two species of Hipparion from Wulanhua have not been found in the Baode area. Previously, the known localities yielding Hipparion platyodus were only Yushe and Wuxiang in Shanxi, and Wudu in Gansu. These are mainly Late Miocene Baodean in age, and this species may have survived in the Early Pliocene Gaozhuangian $[15,16]$. Compared with specimens of the same species from Youfangtou in Hengshan, Shaanxi [15], the lingual valley is wide, the ectoflexid begins to penetrate into the isthmus from $\mathrm{p} 3$, and the protostylid is absent on the specimen of Hipparion teilhardi from Wulanhua. According to these characters, $H$. teilhardi from Wulanhua is more primitive than the population from Youfangtou. Thus, the former's age should be slightly earlier. Compared with the specimens of Plesiaddax depereti from Baode [17], the occipital surface of the Wulanhua specimen is narrower and higher, the 
distance between the horn bases is closer and almost fused. In addition, the anterior border of the horn base is comparatively shifted posteriorly to be situated above the posterior part of the orbit. Compared with the specimens of ?Tragoreas palaeosinensis from Baode [17], the Wulanhua specimen has shorter premolar rows. The former's length ratio of the premolar and cheek tooth rows is $43.3 \%$, while the latter's is $30.9 \%$, so the latter is obviously more derived. The rodent Brachyscirtetes sp. nov. from Wulanhua is clearly smaller in size than $B$. wimani from Ertemte in Huade, Inner Mongolia, comparatively narrower and longer in dental morphology, weaker in lophodont crests, with more primitive characters of the evolutionary lineage of the genus Brachyscirtetes. As a result, the bearing strata may be older than the localities at Ertemte, Harr Obo, and Bilike [18,19]. Judging from these taxonomic components, the age of the Wulanhua Fauna should be between the ages of the Baode and Ertemte faunas, and may be correlated to that of the Baogedawula Fauna in Abag Banner, Inner Mongolia [2,20], with an age of about $7 \mathrm{Ma}$ [21].

The herbivores Chilotherium and Hipparion are dominant members of the Wulanhua Fauna, and other forms include the artiodactyls Cervavitus, Gazella, and Plesiaddax. Thus, this fauna represents an open environment. On the other hand, Sinohippus in the Wulanhua Fauna is a brachydont equid that fed on tender leaves [12], and the two giraffid species fed on higher browse. This indicates that the natural habitat was suitable for animals adapted to a mix of open and closed conditions. In conclusion, the entire of the Wulanhua Fauna seems to imply that this region was a typical steppe during the Late Miocene.

\section{Paleozoogeographical significance}

Based on the distribution of the Neogene mammals, the mammalian faunas of eastern and western China clearly were differentiated during the Early and Middle Miocene. Before the end of the Middle Miocene, a strong boundary extended south-southwest along the eastern border of the Taihang Mountains and reached the eastern borders of the Wudang-Shennongjia Mountains across the Yellow River. In the faunas to the east of this boundary, abundant, low-crowned cervids preferred to live in forests, while in the faunas to the west, great numbers of representative high-crowned bovids lived in open environments. However, previous evidence expounding upon differences between the mammalian faunas of eastern and western China during the Late Miocene has been scarce. Thus, a zoogeographical boundary of the Late Miocene between eastern and western China has not been suggested, while differences of the Hipparion faunas between South and North China have been emphasized, especially the recognition S-N zoogeographical regions related to uplift of the Tibetan Plateau $[3,22]$. Differences between eastern and western China before the Middle Miocene are easily recognized, because they have extremely different ecosystems (i.e. dense forests versus open grasslands). However, since the Late Miocene, eastern dense forests were more sparse and became woodlands under the joint influence of the Tibetan Plateau uplift and an inland arid climate. This modification resulted in more similarities with the western open grasslands, which have not been easy to distinguish. The Tibetan Plateau is located in the southwestern part of China, and its influence decreases along a west to east gradient. Even when the Tibetan Plateau attained great height during the Late Miocene, the zoogeographical boundary between eastern and western China were still not clear. Judging from known faunal components and sedimentary features, the boundary between eastern and western regions of North China did exist at that time, and now the zoogeographical subregions can be recognized. In the eastern part of North China, a series of Hipparion faunas were collected from fluvial sandstones or lacustrine marlites in Mahui of Yushe (Shanxi), Balouhe of Zhangqiu (Shandong), Luwangfen of Xinxiang (Henan), Shala of Sunid Right Banner and Baogedawula of Abag Banner (Inner Mongolia), which are different from the Hipparion red clays of many localities in Baode (Shanxi), Fugu and Lantian (Shaanxi), Qingyang and Linxia (Gansu) in the western part of North China. The southern sector of this boundary is situated between Xin'an and Xinxiang in Henan, and the middle sector is between Baode and Yushe in Shanxi. The north extension of this boundary was impossible to identify accurately in the past, but the discovery of the Wulanhua Fauna now provides convincing evidence, situating it between Siziwang Banner (Wulanhua Fauna) and Sonid Right Banner (Shala Fauna) in Inner Mongolia (Figure 5). During the Late Miocene, the eastern region of this boundary was a humid woodland, persisting since the Early Miocene, while the western region was a dry open steppe that showed a dramatic change after the Middle Miocene, when the area was strongly affected by uplift of the Tibetan Plateau. Compared with the modern zoogeographical regions [23], this boundary shows that the present Chinese zoogeographical distribution has been established along modern lines since the Miocene. After the Middle Miocene Climatic Optimum (MMCO) [24] ended, an abrupt climate change in the Late Miocene resulted in survival of only a few large mammals at the generic level. Conversely, the Pliocene and Quaternary faunas could expand their distributions through long-term adaptive evolution.

Based on faunal components, Chilotherium flourished in the western ecosystem of this zoogeographical division during the Late Miocene, and it became extremely dominant in numbers within this community. The second largest group was composed of various grassland hyenas. They comprised a particular endemic fauna in China. Fossils of the Chinese Chilotherium are unique at the specific level, and differ from the elasmothere Hispanotherium matritense 


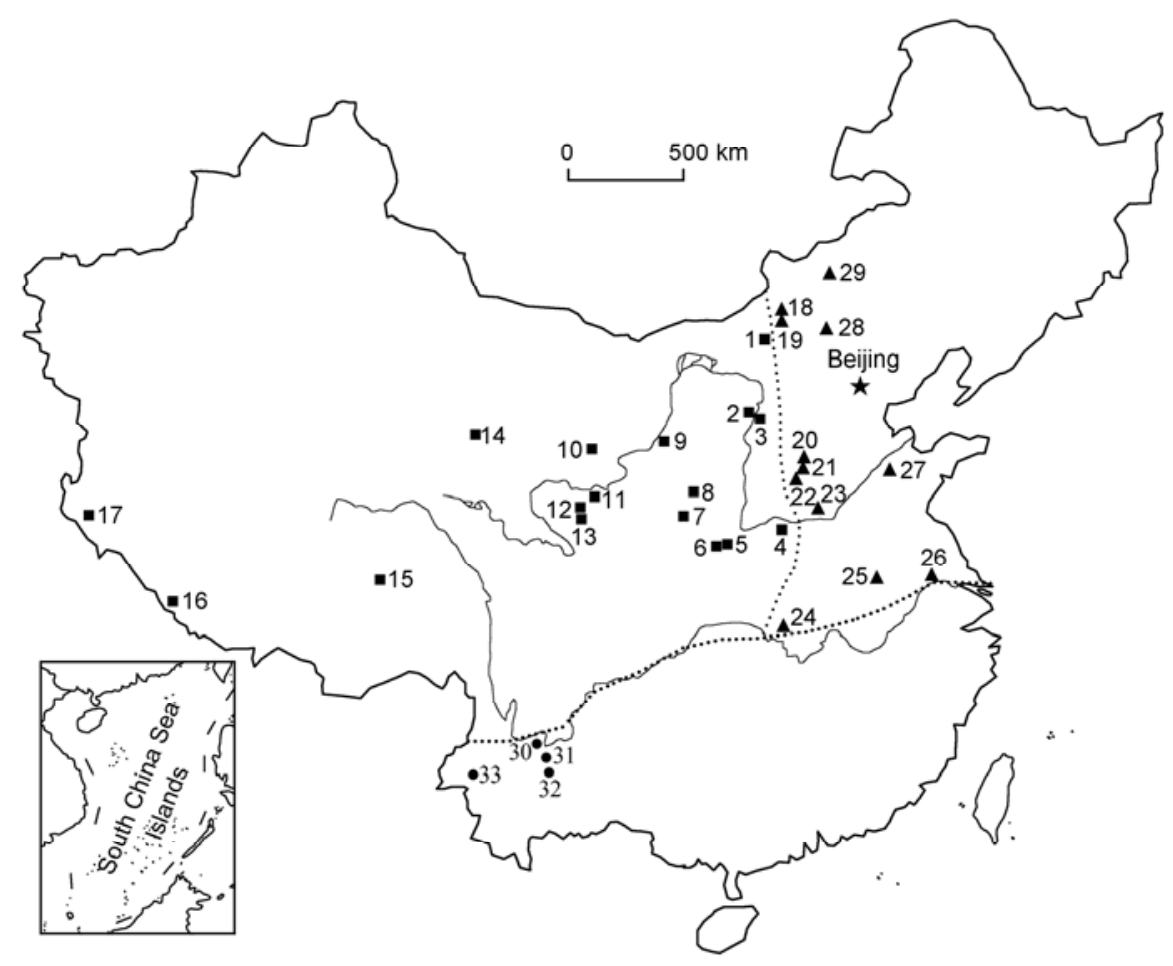

Figure 5 Zoogeographical regions of the Late Miocene in China. Western China (-): 1, Wulanhua; 2, Fugu; 3, Baode; 4, Xin'an; 5, Bahe; 6, Lantian; 7, Lingtai; 8, Qingyang; 9, Wuzhong; 10, Songshan; 11, Guonigou; 12, Yangjiashan; 13, Dashengou; 14, Toson Nor; 15, Bulong; 16, Gyirong; 17, Zanda; Eastern North China (ム): 18, Amuwusu; 19, Shala; 20, Hounao; 21, Jiayucun; 22, Danangou; 23, Luwangfen; 24, Duodaoshi; 25, Laodong; 26, Liuhe; 27, Balouhe; 28, Ertemte; 29, Baogedawula; South China $(\bullet)$ : 30, Yongren; 31, Yuanmou; 32, Lufeng; 33, Baoshan.

that was widely distributed from Western Europe to East Asia at the conspecific level during the Middle Miocene [25]. Although Chilotherium also has been found in other regions of Eurasia, it did not become a significant member in these faunas [26]. In the faunas to the east of this boundary of China, Chilotherium was very rare, while Hipparion fossils dominated. The influence of the Tibetan Plateau during the Late Miocene is not only exhibited in the differences between the eastern and western faunas, but also observed within the western faunas. For example, some forms of the Late Miocene mammalian fauna of the Linxia Basin in Gansu, such as Diceros gansuensis, Hezhengia bohlini, and Dinocrocuta gigantea [27], did not appear in the Baode Fauna of Shanxi.

This zoogeographical boundary, which separates the eastern and western faunas, is approximately close to the boundary between the first and second steps of the modern Chinese topography. Thus, it constituted a geographical barrier to limit migrations for animals. Moreover, the climate and vegetation had very important effects on the distribution of the mammalian faunas on both sides of this boundary [28,29]. However, this type of boundary is not sharply divisional, which is similar to the modern zoogeography, and mammals could mix among faunas between the two sides of the boundary [23]. The Late Miocene Hipparion horse was a typical representative of this ex- change. During the Miocene, the topographies and environments between eastern and western China had differentiated: eastern China was low in elevation, and easily influenced by the warm and humid ocean climate, while western China was high in elevation. Thus, the summer southeast monsoon had little influence in this elevated region, which resulted in evolution of animals and plants clearly different from those of eastern China [30]. The characteristics of the deposits in eastern China (i.e. color, composition and grain size) seem not only to indicate a relatively stable sedimentary environment, but also reflect a condition of higher temperature and regional precipitation during this period [31]. Apparently, such a variation is related to the uplift of the Tibetan Plateau since the Oligocene, because it would have caused varied topography and elevation. These variations not only changed the sedimentary environment and depositional fabrics, but also the climatic pattern in China. These changes influenced the monsoon, which forced the previous east-westerly planetary wind system to be weaker such that clay deposits began to appear over a large area [32,33]. Along with variations of the geographical environment and climate, the faunal and floral component and distribution changed accordingly [3].

This area in Siziwang Banner deposits the northernmost red clays in China, and its latitude is identical to the arid zone in western China, and is even more northward. Red 
clays are considered to represent dust transported by the winter monsoon. Because the winter monsoon blows from the northwest region [34], it indicates that the Mongolian Plateau is one of the important dust sources of red clays in North China.

We appreciate the support of the Bureau of Land and Resources of Siziwang Banner, Inner Mongolia Autonomous Region and Mr. Chen Shanqin of the Hezheng Paleozoological Museum of Gansu Province for assistance with the fieldwork. We are very grateful to Dr. Lawrence Flynn of the Peabody Museum of Archaeology and Ethnology, Harvard University, for his editorial input on this manuscript. This work was supported by the National Natural Science Foundation of China (40730210), the Knowledge Innovation Program of the Chinese Academy of Sciences (KZCX2-YW-Q09-120), and the Ministry of Science and Technology of China (2006CB806400 and 2006FY120300) and China National Commission on Stratigraphy.

1 Wang X M, Qiu Z D, Opdyke N D. Litho-, bio-, and magnetostratigraphy and paleoenvironment of Tunggur Formation (Middle Miocene) in central Inner Mongolia, China. Amer Mus Novitates, 2003, 3411: 1-31

2 Qiu Z D, Wang X M, Li Q. Faunal succession and biochronology of the Miocene through Pliocene in Nei Mongol (Inner Mongolia). Vert PalAsiat, 2006, 44: 164-181

3 Qiu Z D, Li C K. Evolution of Chinese mammalian faunal regions and elevation of the Qinghai-Xizang (Tibet) Plateau. Sci China Ser D-Earth Sci, 2005, 48: 1246-1258

4 Deng T. Chinese Neogene mammal biochronology. Vert PalAsiat, 2006, 44: 143-163

5 Ringström T. Nashörner der Hipparion-Fauna Nord-Chinas. Palaeont Sin Ser C, 1924, 1: 1-159

6 Zdansky O. Jungtertiare Carnivoren Chinas. Palaeont Sin Ser C, 1924, 2: 1-150

7 Bohlin B. Die Familie Giraffidae mit besonderer berucksichtigung der fossilen Formen aus China. Palaeont Sin Ser C, 1926, 4: 1-178

8 Sefve I. Die Hipparionen Nord-Chinas. Palaeont Sin Ser C, 1927, 4: $1-94$

9 Deng T, Wang W M, Yue L P, et al. New advances in the establishment of the Neogene Baode Stage (in Chinese). J Stratigr, 2004, 28: 41-47

10 Yue L P, Deng T, Zhang Y X, et al. Magnetostratigraphy of stratotype section of the Baode Stage (in Chinese). J Stratigr, 2004, 28: 48-51

11 Zhu Y M, Zhou L P, Mo D W, et al. A new magnetostratigraphic framework for Late Neogene Hipparion red clay in the eastern Loess Plateau of China. Palaeogeogr Palaeoclimatol Palaeoecol, 2008, 268: 47-57

12 Hou S K, Deng T, He W, et al. New materials of Sinohippus from Gansu and Nei Mongol, China. Vert PalAsiat, 2007, 45: 213-231

13 Qi T. Several Late Pliocene mammalian fossils from the Damiao area, Inner Mongolia (in Chinese). Vert PalAsiat, 1979, 17: 259-260

14 Zhang X J. The Cenozoic stratigraphical sequence of Linhe region in Neimeng Autonomous Region (in Chinese). Petrol Explor Develop, 1984, 4: 1-8
15 Qiu Z X, Huang W L, Guo Z H. The Chinese hipparionine fossils. Palaeont Sin New Ser C, 1987, 25: 1-243

16 Zhang Y X, Xue X X. Taphonomy of Longjiagou Hipparionine Fauna (Turolian, Miocene) Wudu County, Gansu Province, China (in Chinese). Beijing: Geological Publishing House, 1995. 1-96

17 Bohlin B. Cavicornier der Hipparion-Fauna Nord-Chinas. Palaeont Sin Ser C, 1935, 9: 1-166

18 Qiu Z D, Storch G. The Early Pliocene micromammalian fauna of Bilike, Inner Mongolia, China (Mammalia: Lipotyphla, Chiroptera, Rodentia, Lagomorpha). Senck Leth, 2000, 80: 173-229

19 Qiu Z D. The Neogene mammalian faunas of Ertemte and Harr Obo in Inner Mongolia (Nei Mongol), China. 12. Jerboas - Rodentia: Dipodidae. Senck Leth, 2003, 83: 135-147

20 Tseng Z J, Wang X M. The first record of the Late Miocene Hyaenictitherium hyaenoides Zdansky (Carnivora: Hyaenidae) in Inner Mongolia and an evaluation of the genus. J Vert Paleont, 2007, 27: 699-708

21 Luo X Q, Chen Q T. Preliminary study on geochronology for Cenozoic basalts from Inner Mongolia (in Chinese). Acta Petrol Mineral, 1990, 9: 37-46

22 Tong Y S, Zheng S H, Qiu Z D. Evolution of Cenozoic mammalian faunal regions of China. Vert PalAsiat, 1996, 34: 215-227

23 Zhang R Z. Zoogeography of China (in Chinese). Beijing: Science Press, 1999. 1-502

24 Zachos J, Pagani M, Sloan L, et al. Trends, rhythms, and aberrations in global climate $65 \mathrm{Ma}$ to present. Science, 2001, 292: 686-693

25 Deng T. New material of Hispanotherium matritense (Rhinocerotidae, Perissodactyla) from Laogou of Hezheng County (Gansu, China), with special reference to the Chinese Middle Miocene elasmotheres. Geobios, 2003, 36: 141-150

26 Heissig K. Family Rhinocerotidae. In: Rössner G E, Heissig K, eds. The Miocene Land Mammals of Europe. München: Verlag Dr. Friedrich Pfeil, 1999. 175-188

27 Deng T. Character, age and ecology of the Hezheng Biota from northwestern China. Acta Geol Sin, 2005, 79: 739-750

28 Wang Y, Deng T. A 25-Ma record of paleodiet and environmental change from carbon and oxygen isotopes in mammalian tooth enamel and paleosols from the NE margin of the Tibetan Plateau. Earth Planet Sci Lett, 2005, 236: 322-338

29 Zhang C F, Wang Y, Deng T, et al. $\mathrm{C}_{4}$ expansion in the central Inner Mongolia during the latest Miocene and Early Pliocene. Earth Planet Sci Lett, 2009, 287: 311-319

30 Guo Z T, Peng S Z, Hao Q Z, et al., Late Miocene-Pliocene development of Asian aridification as recorded in an eolian sequence in northern China. Glob Planet Change, 2004, 41: 135-145

31 Ding Z L, Sun J M, Liu T S, et al. Wind-blown origin of the Pliocene red clay formation in central Loess Plateau, China. Earth Planet Sci Lett, 1998, 161: 135-143

32 Ding Z L, Sun J M, Yang S L, et al. Geochemistry of the Pliocene red clay formation in the Chinese Loess Plateau and implications for its origin, source provenance and paleoclimate change. Geoch Cosmoch Acta, 2001, 65: 901-913

33 Sun X J, Wang P X. How old is the Asian monsoon system?-Palaeobotanical records from China. Palaeogeogr Palaeoclimatol $\mathrm{Pa}$ laeoecol, 2005, 222: 181-222

34 Wang P X. Global monsoon in a geological perspective. Chinese Sci Bull, 2009, 54: 1113-1136

Open Access This article is distributed under the terms of the Creative Commons Attribution License which permits any use, distribution, and reproduction in any medium, provided the original author(s) and source are credited. 